\begin{tabular}{|c|cc|}
\hline PORT SAID ENGINEERING JOURNAL & $\begin{array}{c}\text { Faculty of Engineering - Port Said University } \\
\text { No.2 } \\
\text {-Architectural Engineering- }\end{array}$ \\
\hline
\end{tabular}

\title{
The Efficiency of Using Building Integrated Photovoltaics in the Retrofitting of Office Buildings in Egypt
}

\author{
Maha Anber ${ }^{1}$
}

\begin{abstract}
The use of Photovoltaic (PV) technology has spread recently due to its significant contribution to the generation of energy as well as reducing the carbon footprint of buildings. The different materials of the building envelope contribute differently to the energy consumption of the building concerning heat transfer. This research paper aims at studying the efficiency of integrating Building Integrated Photovoltaics (BIPV) in the building skin to reduce energy consumption rates and reduce admitted solar heat gain. This study includes an energy simulation study using an energy simulation software to hold a numerical comparative study between two different types of Building Integrated Photovoltaics (BIPV) that are integrated into the building skin to contribute to reducing the energy demand by the building to determine the most efficient type. Moreover, the research states the feasibility of using them as it is tested along with the payback period of the initial cost of installing them.
\end{abstract}

Keywords: Building integrated photovoltaics (BIPV), Energy simulation, Building envelope, DesignBuilder Software, Payback period

\section{INTRODUCTION}

Atlas Solar radiation of Egypt stated that the annual daily direct solar radiation of Egypt from North to South varies between 5.4 and $7.1 \mathrm{KWh} / \mathrm{m} 2$ [1]. According to the German Aerospace Center evaluation of Egypt's sufficiency of solar potential was estimated by nearly 74 Billion MWh/year [1]. The great potential of Egypt in Solar radiation rates is considered a promising investment aspect not only in economical way but also as an environmental concern by reducing the Carbon Dioxide emissions by substituting oil and coal power stations with renewable energy sources. Although Egypt has massive energy production, its domestic energy consumption rates are high which results on depending on importing hydrocarbon products which negatively affects not only the economy of Egypt but the environment as it results in multiple negative environmental effects[2].

Office buildings consume around $40 \%$ of their energy for lighting to provide an adequate visual environment for their occupant [3]. As shown in figure 1, the energy consumption in Egypt by sector which show that building sector by all its services consume a great sum of energy.

Large glazed curtain walls provide adequate natural light for occupants to achieve indoor visual comfort. Depending on natural light increases productivity and performance of

\footnotetext{
${ }^{1}$ Architecture Department, Higher Institute of Engineering, Shorouk Academy, Cairo, Egypt, email: mahafawzyaly88@gmail.com
}

Received: 22-2-2021, Accepted: 06-07-2021

DOI: $\underline{\text { 10.21608/PSERJ.2021.64601.1095 }}$ users according to many research studies. According to Y. Al Horr, et al (2017), daylighting is the best light source for human visual comfort as well as having a positive impact on improving people's behavior [4]. Another research stated that daylighting improves mental function and reduces depression and violent behavior [5]. It also improves the psychological status of space users. Daylight was proven to have a natural effect of healing due to the connection to the world outside which enhances the connection to nature and results in boosting the occupants' $\operatorname{mood}[6]$.

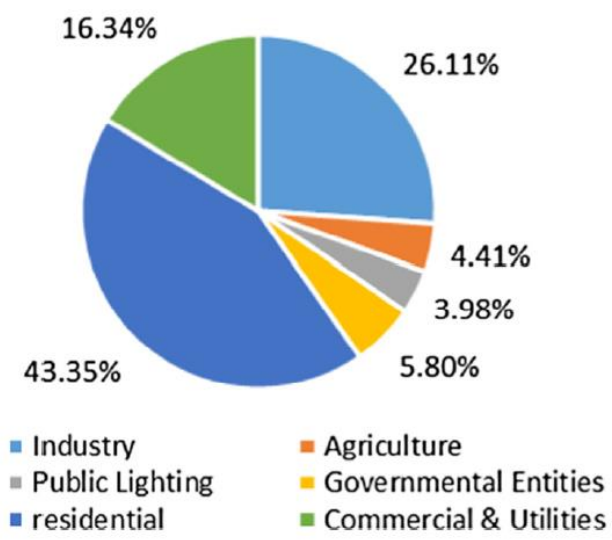

Figure 1: energy consumption in Egypt [4 ]

Using large glazed building facades causes significant heat transfer, which increases the cooling loads and likewise the energy consumption [7]. Building envelopes hold great potential concerning energy savings as they can 
be integrated with renewable energy generation tools to provide energy for the buildings as well as to decrease the negative environmental impact of fossil energy.

Fully glazed facades are responsible for almost $45 \%$ of the cooling demand of buildings [8]. Large, glazed facades result in great energy consumption rates and cause thermal discomfort as they allow for the access of more solar gain [9]. Glazed facades components have great influence on the energy consumption reflected on the air conditioning system and determined by the glazing area, type of glazing and orientation [10].

\section{BUILDING ENERGY RETROFIT}

Building energy retrofit is the renovation or refurbishment of existing buildings to upgrade their energy performance [11]. The inefficiency of existing buildings must be addressed to achieve building sustainability [12]. Applying building energy retrofit measures to reduce the energy inefficiency of buildings and has proven great impact on reducing total energy consumption [13]. According to Luisa F. Cabeza, et al. (2018), in order to achieve energy efficiency in buildings, multiple researches addressed incorporating renewable energy to reduce their carbon footprint and to improve their indoor air quality [14]. S. Attia et al. (2009) stated that among retrofitting strategies, using photovoltaic panels in new and existing buildings can achieve great reduction in electric energy demand [15].

\section{BUILDING INTEGRATED PHOTOVOLTAIC (BIPV)}

BIPV applications can be used on multiple elements of the building envelope such as walls, roofs, and skylights [16]. BIPV systems can operate as an element of the building envelope material and a source generating electricity. They reduce both fossil fuel consumption and greenhouse gas emissions. Moreover, when they are used as a building skin, they achieve materials cost savings [17]. Photovoltaic glazing is a modern innovation in the technology of building glazing that allows the window to keep its functional role besides providing the building with an energy source [18].

Egypt has recently developed an incentive program for people to invest in renewable energy projects and especially photovoltaic cells. These incentives include the reduction of customs for any devices and tools used for renewable energy, fund facilities for renewable energy installations and equipping the national domestic grid with new installations and connections to accommodate renewable energy technologies [19]. In Egypt, installing the photovoltaic system in a high energy consuming project is expected to have payback over a period of five to eight years which is considered very good in terms of investment [20].

\section{CASE STUDY}

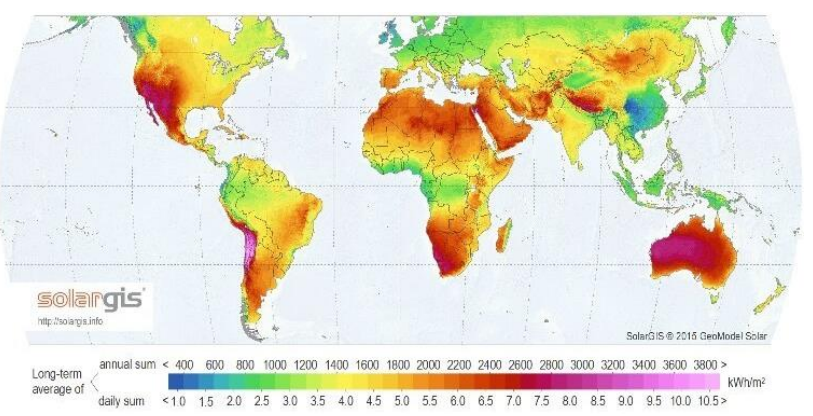

Figure 2: Solar radiation around the world [16]

The research case study was held in an office building located in New Cairo, Cairo, Egypt. As shown in figures three and four, the office-building external glazed facade and its location in new Cairo. The office building is the headquarters of the National Bank of Egypt (NBE). Cairo is chosen as the case study location as it is the capital of Egypt with the largest number of office buildings. It holds a great potential for the use of solar energy applications as means of using renewable energy resources due to its location in hot arid zone according to the world's climate classification with high average solar radiation levels according to Solar GIS as shown in figure number 2 [21], the solar radiation in Egypt is between 5.4 to $7.1 \mathrm{kWh} / \mathrm{m}^{2}$ from north [22].

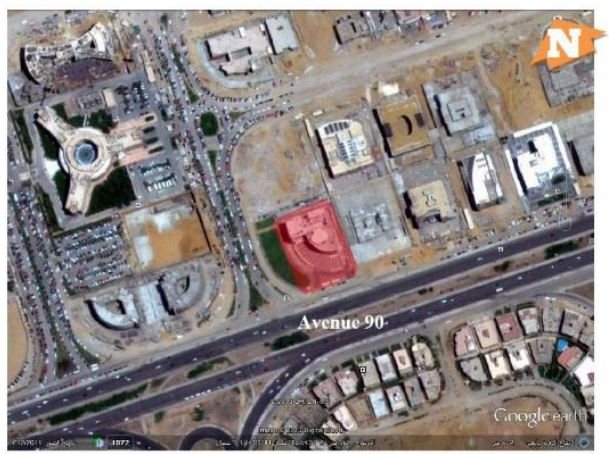

Figure 3: National Bank of Egypt headquarters location- By researcher

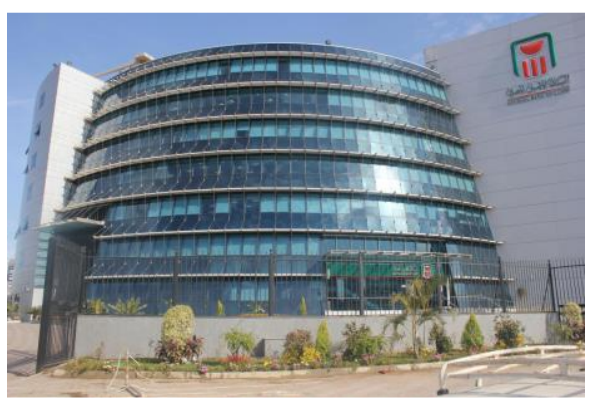

Figure 4: National Bank of Egypt- By researcher 


\subsection{Cairo Climate Summary}

Cairo is located 29 meters above sea level. Its climate is a desert climate and there is no rainfall during the whole year except for a very limited amount in limited months. This climate is categorized under Hot Desert Climate according to Köppen-Geiger climate classification of the world.

The National Bank of Egypt (NBE) building is located in $30^{\circ} 01^{\prime} 02.30^{\prime \prime}$ East, "49.67' $58^{\circ} 63$ North. It is one of the headquarters of the bank accommodating around 700 employees and it has branch dealing with public and an ATM machine.

\subsection{Building Information}

Type: Office building

Owner: National Bank of Egypt

Designer: APG architecture and planning group

The building's total area is $11064 \mathrm{~m} 2$ while its footprint is $1700 \mathrm{~m} 2$. It is a seven-storey building with two basement floors of the parking that are specified for the employees accommodating around 200 cars. The basement floor as well has an armoured room for storing shares and stocks of the bank customers. The bank is an open plan office building that allows various modulation of workspaces. The large curtain wall glazing, with properties mentioned in table 1, allows the maximum penetration of natural daylight as one of the key requirements of a healthy indoor working environment. Solid walls are used in service areas, control rooms and emergency stairs.

Table 1: Curtain wall glass properties- Engineering Administration National Bank of Egypt

\begin{tabular}{|c|c|c|c|}
\hline $\begin{array}{c}\text { Glass } \\
\text { Type }\end{array}$ & $\begin{array}{c}\text { U- Value } \\
\text { (Thermal } \\
\text { Transmittance) } \\
\mathbf{W} / \mathbf{m}^{2} . \mathbf{K}\end{array}$ & $\begin{array}{c}\text { SHGC } \\
\text { (Solar Heat } \\
\text { Gain } \\
\text { Coefficient) }\end{array}$ & $\begin{array}{c}\text { LT (Light } \\
\text { Transmission) }\end{array}$ \\
\hline $\begin{array}{c}\text { Single } \\
\text { glass } \\
6 \mathrm{~mm}\end{array}$ & 6.17 & 0.88 & 0.82 \\
\hline
\end{tabular}

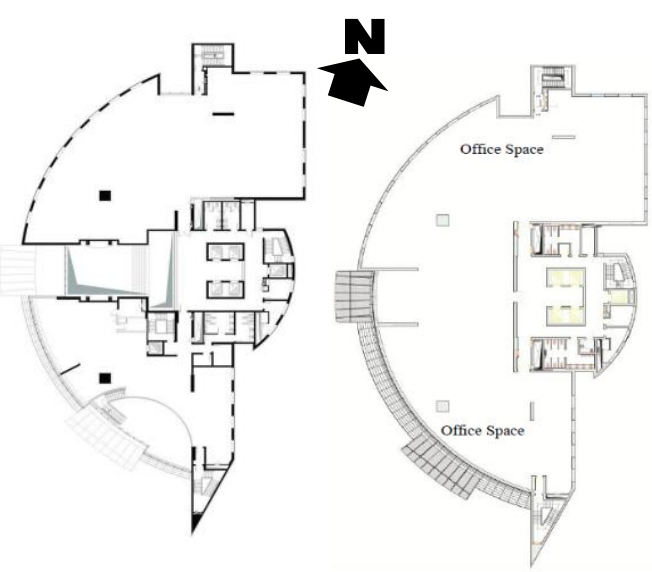

Figure 5: National Bank of Egypt ground and typical floor plans- By researcher

\section{METHODOLOGY}

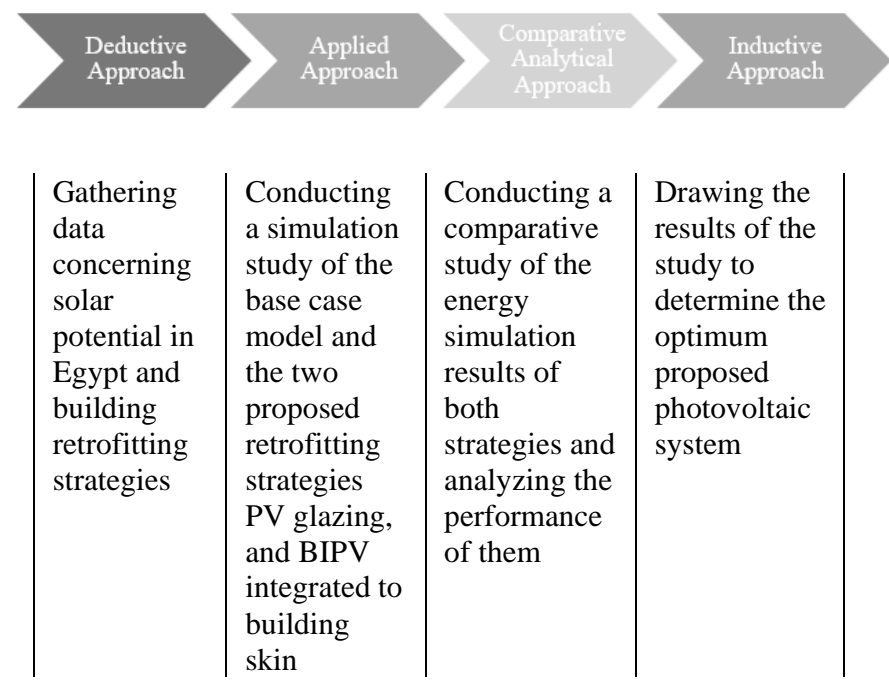

Figure 6: Research Methodology

The methodology that is based on Building Performance Simulation (BPS) depends on modelling the bank building so as to determine the optimum retrofit strategy through numerical simulations which results in a repeated process of retrofitting so as to reach the best retrofit strategy [23] as shown in figure 7 .

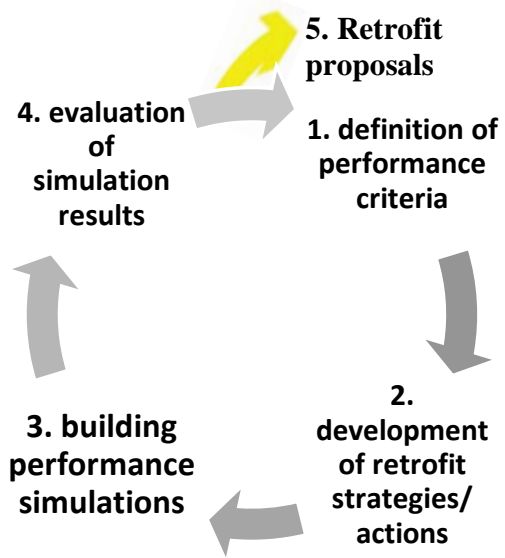

Figure 7: Building performance simulation-based
process [13]

The research methodology is initialized by modelling the National Bank of Egypt headquarters located in the fifth settlement, New Cairo, Egypt in Design Builder software.

The modelling of the building includes the input of all the data of the building construction, building envelope consisting of fenestration, glazing walls, roof, as well as HVAC system, activities, finishing materials, lighting fixtures and appliances.

The applied study is divided into three stages;

\subsection{Stage One}


The energy simulation of Base case model on DesignBuilder software to determine the actual annual energy consumption of the building. As shown in figure 8, the base case model in DesignBuilder software where all the building data were inserted and modeled. Building materials, activity in all spaces, glazing type and HVAC system were modeled to calculate the actual annual energy consumption.

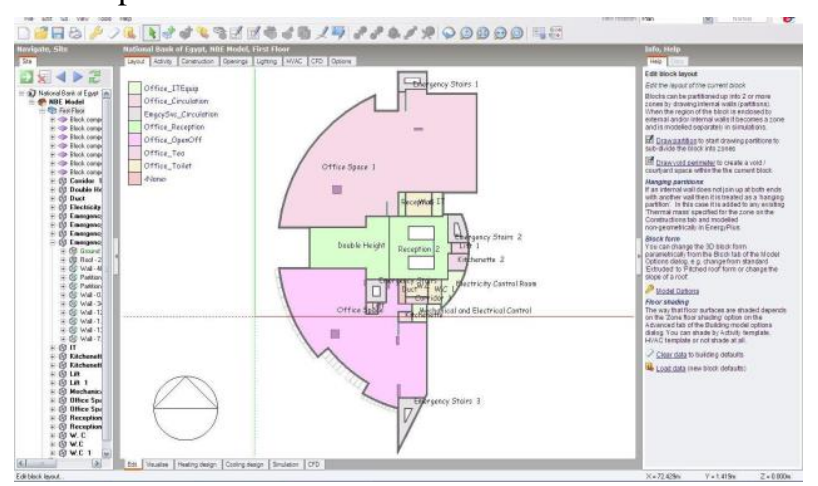

Figure 8: NBE First Floor plan on DesignBuilder software- By researcher

\subsection{Stage Two}

Integrating the Photovoltaics within the building skin on the south elevation with BISOL XL Series, Multicrystalline PV modules/ BXU $340 \mathrm{Wp}$. The thermal, electrical and mechanical specifications are shown in Table 2. These specifications were input in the simulation process so as to determine the energy performance of the substitution of the building skin with Photovoltaic modules. The substituted area from the project's skin to the Photovoltaic modules will be on an area of $680.74 \mathrm{~m}^{2}$.

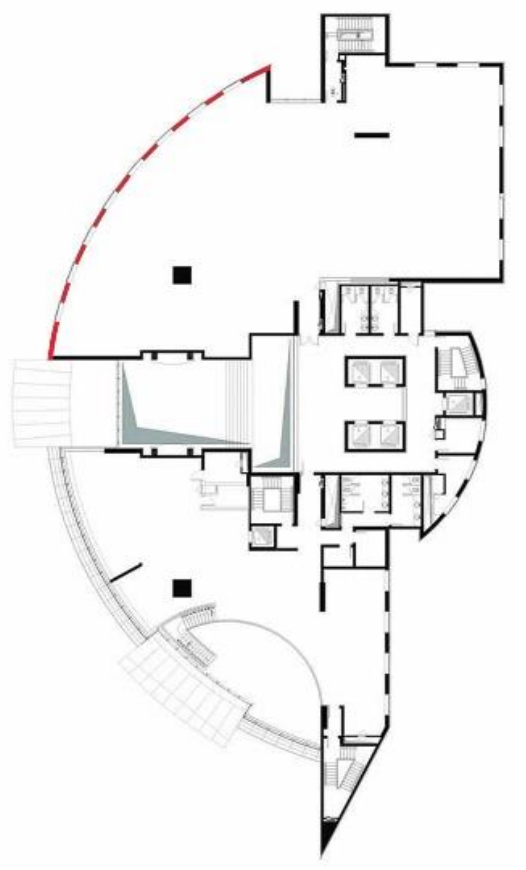

Figure 9: The selected building envelope to be covered by PV modules
Table 2: BISOL XL Series, Multicrystalline PV modules/ BXU 340 Wp Thermal, mechanical and electrical specifications [17]

\begin{tabular}{|c|c|}
\hline \multicolumn{2}{|c|}{ Mechanical Specifications } \\
\hline $\begin{array}{l}\text { Length } \mathrm{x} \text { Width } \mathrm{X} \\
\text { Thickness }\end{array}$ & $1.966 \mathrm{~mm} \times 991 \mathrm{~mm}$ x $40 \mathrm{~mm}$ \\
\hline Weight & $22 \mathrm{~kg}$ \\
\hline Solar Cells & $\begin{array}{c}72 \text { multi c-Si in series / } 156 \mathrm{~mm} \mathrm{X} \\
156 \mathrm{~mm}(6+")\end{array}$ \\
\hline $\begin{array}{l}\text { Junction Box / } \\
\text { Connectors }\end{array}$ & $\begin{array}{c}\text { Three bypass diodes / MC4 } \\
\text { compatible / IP } 67\end{array}$ \\
\hline \multicolumn{2}{|c|}{ Thermal Specifications } \\
\hline $\begin{array}{l}\text { Module efficiency } \eta_{M} \\
(\%)\end{array}$ & 17.5 \\
\hline $\begin{array}{l}\text { Solar Cell efficiency } \\
\eta_{c}(\%)\end{array}$ & 19.2 \\
\hline \multicolumn{2}{|c|}{ Electrical Specifications } \\
\hline $\begin{array}{l}\text { MPP Voltage VMPP } \\
{[\text { V] }}\end{array}$ & 37.2 \\
\hline $\begin{array}{l}\text { Nominal Power PMPP } \\
{[\mathrm{W}]}\end{array}$ & 340 \\
\hline
\end{tabular}

\subsection{Stage Three}

Table 3: Jonsol JSM-72, Thermal, mechanical and electrical specifications [Error! Bookmark not defined.] Mechanical Specifications

\begin{tabular}{|c|c|}
\hline $\begin{array}{l}\text { Length x Width X } \\
\text { Thickness }\end{array}$ & $.956 \mathrm{~mm}$ x $992 \mathrm{~mm}$ x $40 \mathrm{~mm}$ \\
\hline Weight & $24 \mathrm{~kg}$ \\
\hline Junction Box / Connectors & PV- GF20, IP67, 3 diodes \\
\hline \multicolumn{2}{|c|}{ Thermal Specifications } \\
\hline Module efficiency $\eta_{M}(\%)$ & 17.3 \\
\hline Solar Cell efficiency $\eta_{c}(\%)$ & 19 \\
\hline \multicolumn{2}{|c|}{ Electrical Specifications } \\
\hline MPP Voltage $V_{\text {MPP }}[\mathrm{V}]$ & 38.87 \\
\hline Nominal Power PMPP $[\mathrm{W}]$ & 335 \\
\hline
\end{tabular}

\section{RESULTS}

\subsection{Simulation Results for Stage 1}

The simulation of the base case model of the building shows that the annual energy consumption rate is 1414229 KW.h as shown in figure 11 . 


\section{Energy Consumption}

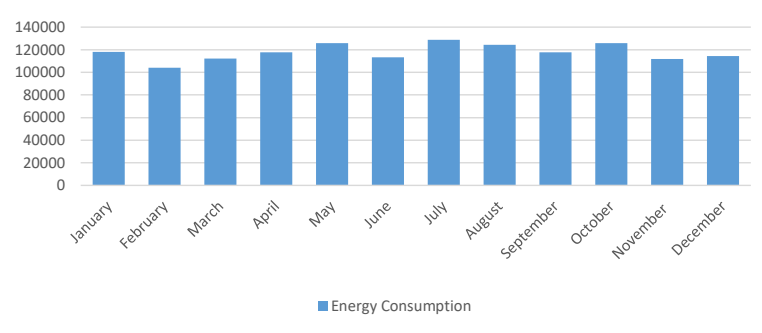

Figure 10: Base case monthly energy consumption simulated on DesignBuilder software- By researcher

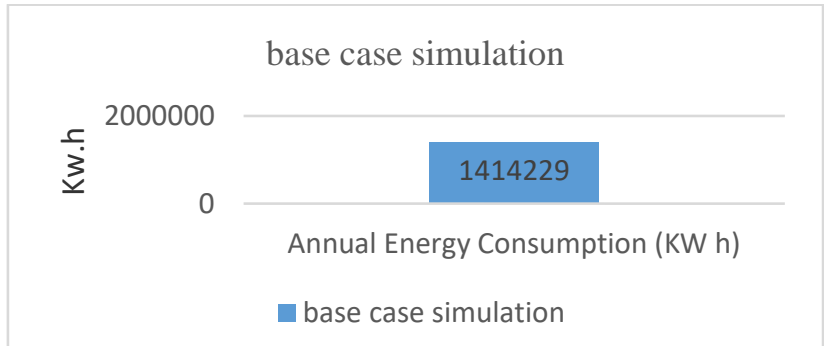

Figure 11: Base case (stage 1) annual energy consumption simulated on DesignBuilder software- By researcher

The simulation of the base case model of the building shows that the annual energy consumption rate is 1414229 KW.h.

\subsection{Simulation Results for Stage 2}

The integration of the BISOL XL PV modules with cell efficiency $19.2 \%$ in the building skin on an area of 680.74 $\mathrm{m} 2$ resulted in the following reductions. The annual energy consumption was reduced from 1414229 KW.h to 1317745 KW.h with a reduction of $6.9 \%$.

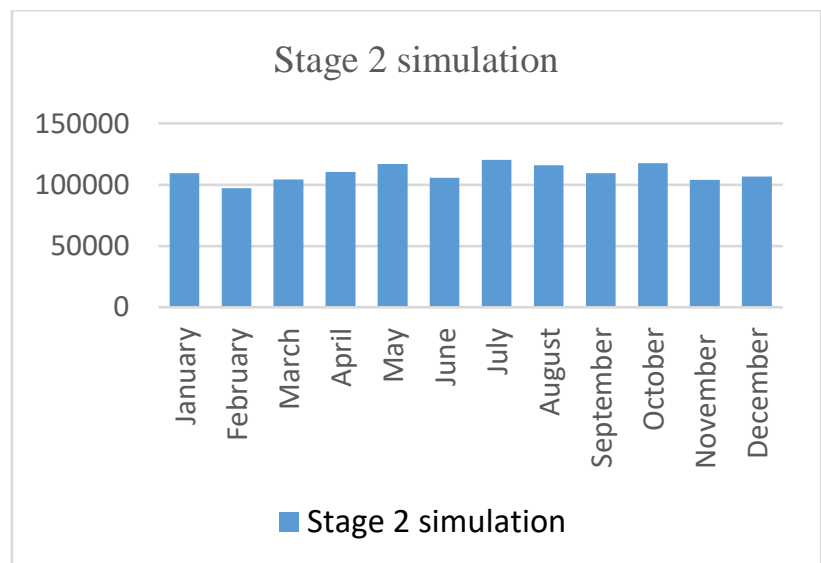

Figure 12: Stage 2 monthly energy consumption simulated on DesignBuilder software- By researcher

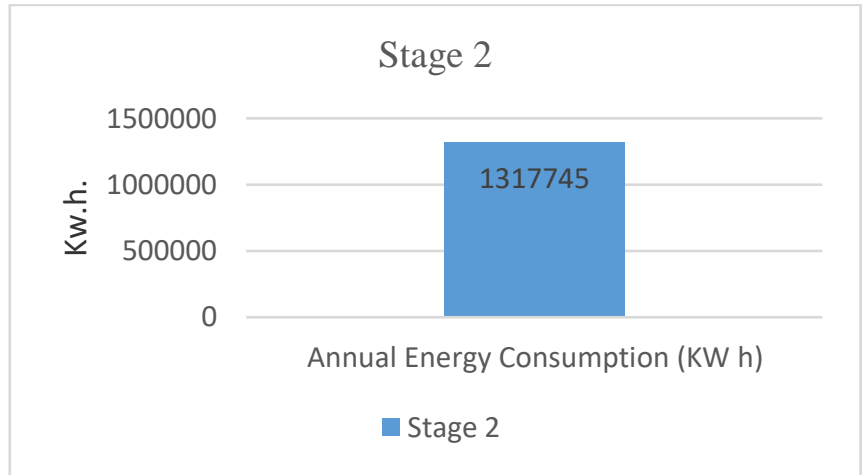

Figure 13: Stage 2 annual energy consumption simulated on DesignBuilder software- By researcher

The simulation of stage 2, integrating the BISOL XL Series, Multicrystalline PV modules/ BXU $340 \mathrm{Wp}$ in the elevation resulted in an annual energy consumption reduction from 1414229 to $1317745 \mathrm{KW}$.h. of the total energy consumption as shown in figure number 13.

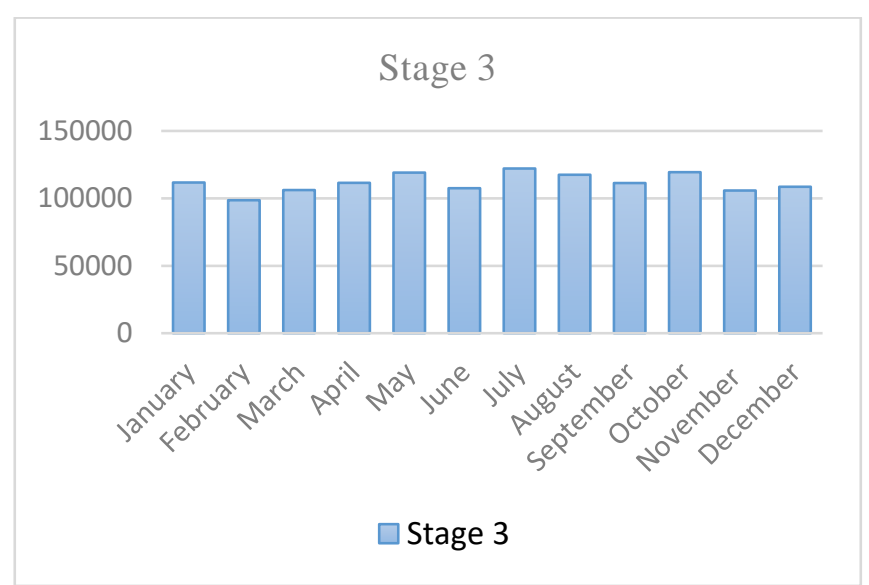

Figure 14: Stage 3 monthly energy consumption simulated on DesignBuilder software- By researcher

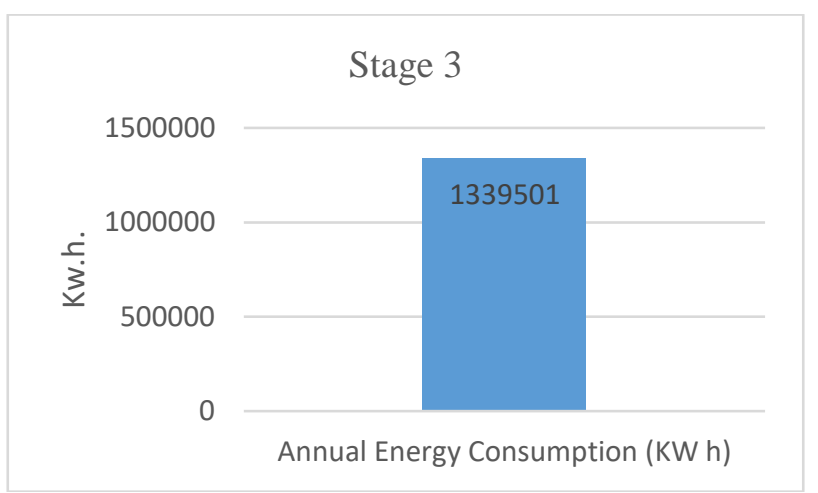

Figure 15: Stage 3 annual energy consumption simulated on DesignBuilder software- By researcher

The integration of the Jonsol JSM-72 PV modules with cell efficiency $19 \%$ in the building skin on an area of $680.74 \mathrm{~m} 2$ resulted in the following reductions. The annual energy consumption was reduced from 1414229 KW.h to 
$1339501 \mathrm{KW}$.h with a reduction of $5.2 \%$ of the total energy consumption as shown in figure 15 .

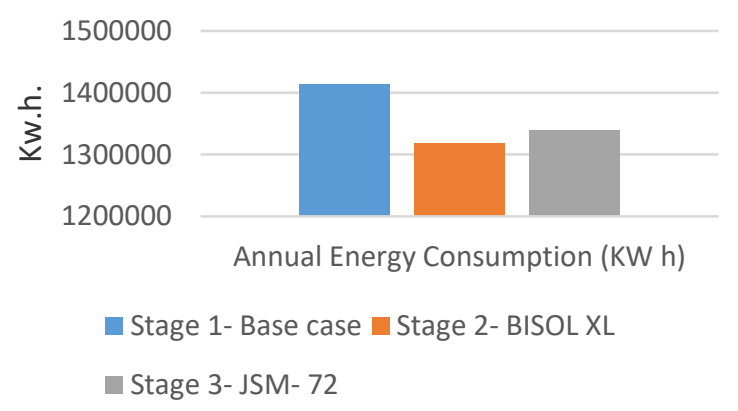

Figure 16: Annual energy consumption simulated on DesignBuilder software for the three stages- By researcher

The comparative study presented at this scientific research by applying retrofit strategies to the building envelope by partially replacing it with Photovoltaic modules.

In stage 1, a base case simulation study was held in order to determine the annual energy consumption as a benchmark to measure the extent to which the energy consumption will be affected by using photovoltaic cells. The simulation of the base case model of the building shows that the annual energy consumption rate is 1414229 KW.h.

In stage 2, the partial replacement of the building envelope with BISOL XL Series achieved energy saving of a cost of $9648.4 \$$ per year with an initial cost of around $55564 \$$ and a payback period of 5.8 years.

In stage 3 , the partial replacement of the building envelope with Jonsol JSM-72 achieved energy saving of a cost of 7472.8 \$ per year with an initial cost of $48550 \$$ and a payback period of 6.5 years.

Stage two proved more efficiency and feasibility because of its higher energy saving potential along with shorter payback period.

Table 4: Retrofit cost for building integrated photovoltaics (BIPV) (Stages $1 \& 2$ ) [22][24]

\begin{tabular}{lcccc}
\multicolumn{1}{c}{ Unit } & $\begin{array}{c}\text { Area } \\
\left(\mathbf{m}^{2}\right)\end{array}$ & $\begin{array}{c}\text { Cost/ } \\
\text { pieces } \\
\text { (USD) }\end{array}$ & $\begin{array}{l}\text { Number } \\
\text { of pieces }\end{array}$ & $\begin{array}{c}\text { Total } \\
\text { cost } \\
\text { (USD) }\end{array}$ \\
$\begin{array}{l}\text { BISOL } \\
\text { XL Series }\end{array}$ & 680.74 & 159.21 & 349 & 55564 \\
$\begin{array}{l}\text { Jonsol } \\
\text { JSM-72 }\end{array}$ & 680.74 & 138.32 & 351 & 48550 \\
\hline
\end{tabular}

Table 5 Energy saved and payback period for Stage 2 (BISOL XL Series) [22]

\begin{tabular}{|l|c|}
\hline \multicolumn{1}{|c|}{ BISOL XL Series } & $680.74 \mathrm{~m}^{2}$ \\
\hline Cell efficiency & $17.5 \%$ \\
\hline Total cost & $55564 \$$ \\
\hline Electricity price & $0.10 / \mathrm{KWH}$ \\
\hline Generated electricity & $96484 \mathrm{KWH}$ \\
\hline Savings & $96484 * 0.1=9648.4$ per year \\
\hline Payback period & $55564 / 9648.4=5.8$ years \\
\hline
\end{tabular}

Table 6 Energy saved and payback period for Stage 3 (Jonsol JSM-72) [24]

\begin{tabular}{|l|c|}
\hline \multicolumn{1}{|c|}{ Jonsol JSM-72 } & $680.74 \mathrm{~m}^{2}$ \\
\hline Cell efficiency & $17.3 \%$ \\
\hline Total cost & $48550 \$$ \\
\hline Electricity price & $0.10 / \mathrm{KWH}$ \\
\hline Generated electricity & $74728 \mathrm{KWH}$ \\
\hline Savings & $74728 * 0.1=7472.8$ per year \\
\hline Payback period & $48550 / 7472.8=6.5$ years \\
\hline
\end{tabular}

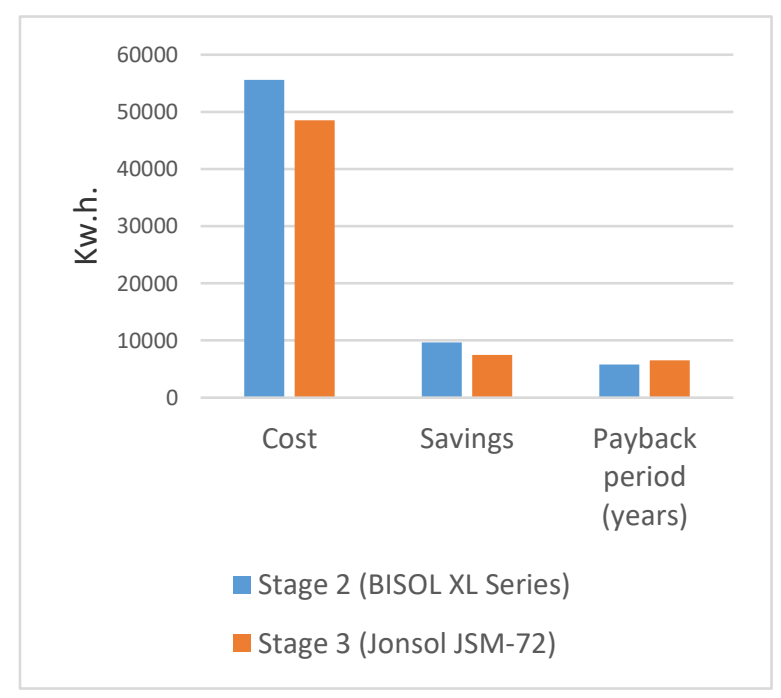

Figure 17: Stages 2 and 3 comparison (cost, savings and payback period)

\section{CONCLUSIONS}

The comparative study held in this research between two different types of BIPV (building integrated photovoltaics), BISOL XL Series, Multicrystalline PV modules/ BXU $340 \mathrm{Wp}$ and Jonsol JSM-72 PV modules. The performance of these modules was good although their placement in a limited area of the building envelope. Building envelope thermal properties are significant factors determining the buildings' energy consumption rates. This result in the fact that retrofit strategies applied to the building envelope components have a great impact on the energy consumption of buildings. The integration of photovoltaic modules in the building envelope is very suitable in Egypt and MENA (Middle East and North Africa) region in general due to the high solar radiation at this area. Energy simulation studies are a reliable means of holding computer analysis of the energy performance of buildings and the retrofit strategies applied to them. According to the energy simulation processes that were held in this research paper, the performance, savings and payback period of using BISOL XL Series is better and has bigger energy saving potential.

\section{Declaration of competing Interest}

The authors declare that they have no known competing financial interests or personal relationships that could have appeared to influence the work reported in this paper. 


\section{REFERENCES}

[1] Mortensen NG, Said US, Badger J. Wind atlas for Egypt. In measurements and modelling 1991- 2005. Cairo/Roskilde: NREA and Egyptian Meteorological Authority/Risø National Laboratory; 2005.

[2] A.F. Radwan et al., Retrofitting of existing buildings to achieve better energy-efficiency in commercial building case study: Hospital in Egypt, Alexandria Eng. J. (2016), http://dx.doi.org/10.1016/j.aej.2016.08.005

[3] Xu, L., Y. Pan, Y. Yao, D. Cai, Z. Huang, and N. Linder. 2017. "Lighting Energy Efficiency in Offices Under Different Control Strategies." Energy and Buildings 138: 127-139.

[4] Y. Al Horr, M. Arif, A. Kaushik, A. Mazroei, E. Elsarrag, S. Mishra, Occupant productivity and indoor environment quality: a case of GSAS, Int. J. Sustain. Built Environ. 6 (2) (2017) 476-490.

[5] L. Edwards, P. A. Torcellini, and N. R. E, "A literature review of the effects of natural light on building occupants," National Renewable Energy Laboratory, 2002.

[6] L. Gelfand, E. C. Freed, Sustainable School Architecture: Design for Elementary and Secondary School, John Wiley and Sons Inc.

[7] E. Halawa et al., 2018 "A review on energy conscious designs of building façades in hot and humid climates: Lessons for (and from) Kuala Lumpur and Darwin", Renewable and Sustainable Energy Reviews, vol. 82, pp. 2147-2161.

[8] NEVEEN, H., 2008 "Double versus single skin facades in hot arid areas". Energy and Buildings. v. 40

[9] H. Wong et, al. (2005) "Effects of double glazed facade on energy consumption, thermal comfort and condensation for a typical office building in Singapore" Energy and Buildings 37 (2005) 563-572.

[10] PALMER, C. M.; GENTRY, T. A Better Distinction for Standard Specifications of Low-E Coatings for Diverse Climate Conditions. PLEA. Proceedings...North Carolina at Charlotte USA, 2012

[11] Malatji EM, Zhang J, Xia X (2013) A multiple objective optimisation model for building energy efciency investment decision. Energy Build 61:81-87

[12] Alam, Morshed \& Zou, Patrick \& Sanjayan, Jay \& Stewart, Rodney \& Sahin, Oz \& Bertone, Edoardo \& Wilson, John. (2016). Guidelines for Building Energy Efficiency Retrofitting.

[13] Chidiac, S.E., et al., A screening methodology for implementing cost effective energy retrofit measures in Canadian office buildings. Energy and Buildings, 2011. 43(2-3): p. 614-620.
[14] Luisa F. Cabeza, Alvaro de Gracia, Anna Laura Pisello (2018) "Integration of renewable technologies in historical and heritage buildings: A review" Energy \& Buildings 177 (2018) 96-111- ELSEVIER.

[15] S. Attia et al. (2009) "Impact and potentials of community scale low-energy retrofit: case study in Cairo" Proceedings of the 3rd CIB International Conference on Smart and Sustainable Built Environment, TU Delft, Delft

[16] G.M. Tina, A.Gagliano, F. Nocera, F.Patania (2013) "Photovoltaic glazing: analysis of thermal behavior and indoor Comfort" The Mediterranean Green Energy Forum 2013, MGEF-13. ELSEVIER.

[17] Aguacil S., Lufkin S., Rey E. Architectural design scenarios with building- integrated photovoltaic solutions in renovation processes: Case study in Neuchâtel (Switzerland). In: PLEA 36th International Conference on Passive and Low Energy Architecture. Cities, Buildings, People: Towards Regenerative Environments. Los Angeles; 2016.

[18] B. Norton, P.C. Eames, T.K. Mallick, M.J. Huang, S.J. McCormack, J.D. Mondol, Y.G. Yohanis, Enhancing the performance of building integrated photovoltaics, Solar Energy 85 (8) (2011) 1629-1664.

[19] International Energy Agency (IEA). https://www.iea.org/policiesand\%20measures/pams/e gypt/name-24583-en.php, Retrieved on October, 2020

[20] Ibrahim A. (2015) Renewable energy sources in the Egyptian electricity market: a review in renewable and sustainable energy reviews 2015; 16:216-230.

[21] Solar GIS. 2019. Available online: https://solargis.com/ (accessed on 22 January 2020).

[22] BIOSL Solar Company. BISOL PV Modules; Bisol production Ltd.: Prebold, Slovenia, 2020. Available online:

https://www.bisol.com/en/products/pv-modules.html (accessed on 20 January 2020).

[23] Mondrup, T.F.; Karlshøj, J.; Vestergaard, F. Building Performance Simulation tools for planning of energy efficiency retrofits. In 10th Nordic Symposium on Building Physics; Lund University: Lund, Sweden, 2014.

[24] Jonsol GmbH Bergweg 8271134 Aidlingen Deutschland, Available online on: www.jonsol.com 